\title{
Analisis faktor kesalahan sebagai unsur dolus dalam tindak pidana merampas nyawa milik orang lain dalam perkara no 328/PID/2017/PT.DKI
}

\author{
Koko Joseph Irianto \\ (Mahasiswa Program S1 Fakultas Hukum Universitas Tarumanagara) \\ (E-mail: kokojosephirianto@gmail.com)
}

\section{Dr. Dian Adriawan Dg Tawang.S.H,M.H.}

(Corresponding Author)

(Dosen Fakultas Hukum Universitas Tarumanagara. Meraih Sarjana Hukum pada Fakultas Hukum Universitas hassanudin, Magister Hukum pada Fakultas Hukum Universitas hassanudin, Doktor (Dr.) pada Fakultas Hukum Universitas hassanudin)

(E-mail: dianadriawan@fh.untar.ac.id)

\begin{abstract}
Koko Joseph irianto, (205130115), Faculty of Law at Tarumanagara University, with the title of the thesis "Analysis of the error factor as an element of dolus in a crime to take the life of another person in a case NO: 328 / PID / 2017 / PT.DKI ". Under the guidance of Mr. DR.DIAN ADRIAWAN, S.H, M.H. This study aims to analyze the legal arrangements regarding criminal acts of premeditated murder by a group of people in Decision Number: no: 328 / PID / 2017 / PT.DKI. This research was carried out in the city of Jakarta by selecting agencies related to this case namely in the Jakarta High Court. Data collection method used is documentation study method then the data obtained is analyzed descriptively qualitative so as to reveal the expected results and conclusions on the problem. The results of this study indicate that 1) Legal arrangements for criminal acts of murder have been regulated in general in the Criminal Code $(K U H P)$. And the murder plans to be in article 340 of the Criminal Code 2) The application of the material criminal law to the perpetrator of the Murder criminal act is appropriate, as regulated and threatened with criminality in Article 340 of the Criminal Code. Judicial legal considerations in imposing death penalty on 2 and 1 prisoners for life of the defendants from 4 perpetrators who are still alive is correct. The conviction of the defendant was considered to have fulfilled a sense of justice for all parties.
\end{abstract}

Keywords:proof, Court, murder, Criminal law, defendant. 


\section{PENDAHULUAN}

\section{A. Latar Belakang}

Dalam Pasal 1 ayat 3 tiga Undang-Undang Dasar (UUD) Negara Republik Indonesia tahun 1945 ingin sekali berkata dan memang sesuai fakta bahwa Indonesia adalah negara hukum/rechstaat, ${ }^{1}$ ) dan sama sekali tidak belaka/machtstaat. Hukum itu sendiri adalah hukum sangatlah tidak berbentuk karena dapat diartikan setiap orang berbeda-beda tergantung darimana dia memahaminya dan mengartikannya. ${ }^{2)}$ Menurut pendapat Achmad Ali seorang ahli hukum, hukum adalah:

"sekumpulan kaidah ataupun tolak ukur yang sistematis di dalam satu sistem yang Diana dapat memberi hasil apakah itu ya atau tidak dilakukan oleh seseorang yang tercantum sebagai warga suatu negaradi dalam kehidupannya. Hukum itu sendiri asalnya dari warga itu sendiri atau yang lainnya yang dipandang adanya di dalam kewargaan itu, juga dilakukan oleh warga dikehidupan keseluruhnya. Jika itu dilanggar yang tertinggi akan memberikan hukuman yang berbentuk eksternal”. 3)

Menurut ahli hukum Van Apeldoorn peristiwa pidana memiliki dua segi hukum yaitu segi objektiff dan segi subjektiff. Adapun yang dimaksud dengan segi objektif, maka peristiwa pidana adalah suatu tindakan berbuat atau pun yang tidak berbuat yang bertentangan dengan hukum yang positif dan tentunya bersifat tanpa hak/onrechtmatigheid. ${ }^{4}$ ) Dilihat dalam garis besarnya dengan bertolak pada kodifikasi sebagai sumber yang paling utama atau sumber pokok hukum pidana yang ada di indonesia. Hukum pidana adalah merupakan jenis perbuatan ataupun

1) Indonesia, Undang-Undang Dasar Negara Republik Indonesia Tahun 1945. Pasal 1 ayat (3) tiga.

\footnotetext{
2) Achmad Ali, Menguak Tabir Hukum, (Bogor: Ghalia Indonesia,2008), hal 1

3) ibid., hlm. 30 .

4) L.J.Van apeldoorn,"Pengantar Ilmu Hukum", (Jakarta: Pradnya paramita), hal 326.
} 
pelanggaran yang ditambahkan dengan hukuman pidana. ${ }^{5)}$ penjatuhan sanksi pidana dalam arti umum adalah bidang dari pembentuk Undang-Undang karena asas legalitas, yang berbunyi nullum dellectum noella poena siena previa lege poenali. Oleh karena itu untuk mengenakan poena atau pidana diperlukan UndangUndang pidana terlebih dahulu. Pembentuk Undang-Undang itu sendiri yang menetapkan peraturan tendang pidananya, tidak hanya tentang crimen atau delectum, adalah tentang juga tindak pidana mana yang dapat dikenakan pidana. ${ }^{6}$ ) Hukum pidana merupakan suatu bagian dari hukum publik yang berisi tentang:

1. Peraturan hukuman pidana saling berkaitan dengan larangan-larangan untuk lakukan perbuatann sesuatu yang disertai ancam hukuman kurungan atau disebut juga dalam bahasa Belanda strafbarfeit untuk yang melanggar larangan itu.

2. Ketentuan sesuatu yang mengerucut yang memang seharusnya difullkan atau.

3. Cara yang berkenan atau sebagusnya dilakukann suatu bangsa lewat yang tersedia di dalam suatu bangsa contohnya: Polri, badan peradilan,kejaksaan, dan majelis tertuju pada yang dianggap melewati garis yang sudah ditentukan dalam bangsa yang menjatuhkan, mentukan, dan melakukan hukuman terhadap dirinya, Ida perlakuan yang diusahakan yang boleh dan sebaiknya dilakukan oleh yang disaangkakan atau yang berkaitan dengan ini manusianya di dalam upaya untuk melindungi dan mengingini yang baik hak-haknya dari sifat bangsa yang ingin meninggikan hukum tersebut hukum pidana yang punya pertama dan selanjutnya dikatakan hukum material yang isinya dari adalah kitab undang undang hukum pidana dari pada itu hukum yang isinya tentang keyiga itu adalah hukum formil yang isinya intinya adalah undang undang no8 thn 2981 di sebut juga kitab undang undang hukum acara pidana

5) Yan Pramadya Puspa, Kamus Hukum Edisi Lengkap Bahasa Belanda, Indonesia Inggris, (Semarang: Aneka Ilmu, 1977). hal 823.

6) Djoko Prakoso, Masalah Pemberian Pidana dalam Teori dan Praktek Peradilan. cetakan ke-1, (jakarta: Ghalia Indonesia, 1984) hal. 15. 
Masyarakat ialah salah satu organ negara yang harus dilindungi oleh hukum, maka dari itu alinea ke 4 undang-undang dasar negara republik indonesia sangat melindungi masyarakat yang berbunyi:

"Kemudian daripada itu untuk membentuk suatu Pemerintah Negara Indonesia yang melindungi segenap bangsa Indonesia dan seluruh tumpah darah Indonesia dan untuk memajukan kesejahteraan umum, mencerdaskan kehidupan bangsa, dan ikut melaksanakan ketertiban dunia yang berdasarkan kemerdekaan, perdamaian abadi dan keadilan sosial, maka disusunlah kemerdekaan kebangsaan Indonesia itu dalam suatu UndangUndang Dasar Negara Indonesia, yang terbentuk dalam suatu susunan Negara Republik Indonesia yang berkedaulatan rakyat dengan berdasar kepada Ketuhan Yang Maha Esa, Kemanusiaan yang adil dan beradab, Persatuan Indonesia, dan Kerakyatan yang dipimpin oleh hikmat kebijaksanaan dalam permusyawaratan/perwakilan, serta dengan mewujudkan suatu keadilan sosial bagi seluruh rakyat Indonesia,"7)

Dari kelima Pancasila dari kata Pancasila yang keberadaanya ada sampai hari ini. Itu objek tersebut adalah 1 dari 4 pokok kebangsaan yang sebagusnya dijaga. Tanpa adanya yang tadi disebutkan di atas tidak tahu lagi apa yang akan kejadian pada bangsa ini. Oleh karena itu objek tersebut adalah pegangan bangsa ini untuk di asakannya persatuan dari bangsa Indonesia yang kita cintai ini.

Kepolisian RI meriset banyaknya perkara konvensional di tahun 2017 yang terkena penurunan yang sebesar 27\% dari yang sebelumnya berubah jadi 235.350 perkara. Jendral polisi Ito karnavian sebagai kapolri di masa Noya mengemukakan kriminal di tahun sebelumnya Ika dijumlahkan tembus di angka 322.557 perkara. Polri sendiri menblok blokan kriminalitas konvensional didirikan menjadi ranmor atau pencurian kendaraan bermotor, pencurian dan pemberatan, penipuan 378,

\footnotetext{
7) Indonesia. Pembukaan Undang-Undang Dasar Negara Republik Indonesia Tahun 1945, alinea ke-4.
} 
penganiyaaan berat,penggelapan,, kemudian perampokan dengan kekerasan. Di tahun 2016 jumlah perkara pencuriandengan pemberatan yang dilakukan dikala bencana atau dengan kata lain dengan pemberatan atau pencurian biasapun bisa mencapai 36.448 perkara. Dilanjutkan kemudian di tahun 2017 jumlahnya menurun menjadi 30.658 perkara, yang dapat diartikan menjadi penurunan yang sangat baik sebesar 16\%. Di bagian lainnya perkara pencurian motor mobil atau semua kendaraan pada tahun 2016 banyaknya mencapai 34.756 kemudian di tahun 2017 juga ikut menurun sampai 17\% sehingga jumlahnya jadi 28.624 bagus sekali. Disisi lainnya juga ada kasus penipuan di pasal 378 KUHP itu juga ikut turun sehingga mencapai 17\% karena di tahun 201627.330 perkara dan baiknya di tahun 2017 ada penurunan lagi di angka 23.367 perkara turun 14\%. Lainnya lagi penggelapan, juga mengalami penurunan yang masih dibilang sedikit yaitu $18 \%$ yang pada 2016 kejadian 19.585 perkara yang baiknya di tahun 2017 hanya terjadi 15.934 perkara. Termasuk didalamnya kasus pencurian atau perampokan dengan disertai kerasan juga penurunan yang terjadi besarnya 22\% pada tahun 2016 dihitung ada 10.060 perkara itu sekarang di tahun 2017 berubah menjadi 7.834 perkara di tahun 2017. Namun sayang sekali di perkara penganiyayan yang berat ini malah alami peningkatan tinggi banyaknya 12\% yang Diana tahun 2016 hanya 11.942 perkara menjadi 13.359 perkara di tahun 2017 sunggu sangat disayangkan. dapat disimpulkan banyak sekali kejahatan di Indonesia yang sangat membahayakan NKRI walaupun banyak yang turun persentasenya. ${ }^{8)}$.

Pandangan umum tentang pidana yang biasanya diterjemahkan sama adalah penghukuman tapi 2 itu ada pemahaman yang berbeda sekali hukuman adalah sesuatu yang menyakitkan terhadap orang yang melakukan tindak pidana tapi pidana adalah pemahaman khusus yang ada hubungannya dengan hukum pidana itu sendiri. Dijadikan pemahaman sendiri, terletak kesamaan juga dengan pemahaman umum adalah hukuman yang membuat pusing yang memenderitakan

\footnotetext{
${ }^{8)}$ Shenny Fierdha,"polisi catat jumlah kriminal", www.anadoluagency.com, 29 desember 2017.
} 
seseorang. ${ }^{9)}$ perbincangan konsep dilingkungan penggunaan pidana sepanjang kehidupannya dan hukuman mati sebagai alat penanggulangan kejahatan itu sudah ada dari berkembangbiaknya falsafah pembina atau yang biasa disebut treatment philosofi di dalam pidnaan. Perbincangan tentang hukuman sepanjang hidup angan keras karena menaiknya issue global mengenai hak asasi manusia atau disebut HAM ${ }^{10)}$

Ahli hukum bernama Soedarto berkata jika yang adalah pidana itu sendiri artinya beban penderitaan yang diberikan kepada seseorang yang dalam hidupnya lakukan perbuatan pidana itu sendiri dan memenuhi beberapa syarat yang telah ditentukan ${ }^{11}$ kitab undang undang hukum pidana ialah peraturan perundang undangan yang aturannya mengenai pembutan seorang yang bisa disebut material. Kitab undang indang hukum pidana yang berlaku sekarang ialah kitab undang undang hukum pidana yang asalnya dari jaman pernjajahan Belanda sebelum tahun 1945. Disahkan pada tahun 1915 nomo 723. Hal ini berdasarkan pada Ketentuan Peralihan Pasal 2 UUD tahun 1945 yang mengatakan bahwa: diberlakukan dari 1 jan 1918 setelah kemerdekaan negara republik Indonesia, kitab undang undang hukum pidana dibolehkan dengan ditambah pengertian kondisi dengan cara mencabut pasal pasal yang tidak dibutuhkan lagi. Hal inilah yang didasarkan dari ketentuan pasal Undang undang dasar tahun 45 yang menyatakan bahwa:

"Segala badan negara dan peraturan yang masih ada langsung diberlakukan selama belum diadakan yang baru menurut Undang-Undang Dasar ini."

Ketentuan ketentuan inilah yang dijadikan pilar hukum dari yang diberlakukan keseluruhan undang undang pada penjajahan Belanda di waktu lampau terhadap

\footnotetext{
9) Andi hamzah, stelsel pidana \& pemidanaan di Indonesia, Pradja Paramita, Jakarta,1993, hal 1.

10 ) tonggat, pidana seumur hidup dalam sistem hukum pidana di Indonesia, UMM Press, malang,2005, hal1.

${ }^{11)}$ Widya priatno, sistem pelaksanaan penjara di Indonesia, PT:refika aditama, Jakarta,2005, hal
} 
bangsa Indo dan di masa masa kemerdekaan. Dengan tujuan untuk mengadakan kembali hukum hukum itu, maka di tanggap 26 feb 1946, pejabat Indonesia membuat undang undang no 1 tahun 1946 mengenai peraturan hukum pidana. Undang2 itu yang menjadi llandasan perubahan hukum yang terdahulu yang dikenal dengan kitab undang undang hukum pidana atau sering disebut KUHP dengan itu, pasal 17 undang- undang nomor 2 tahun 1986 juga ada yang mengatakan bahwa hanya berlaku di Madura dan Jawa dan hara terbatas itu pada hari itu di beritahukan dan diproduksi di tempat lainnyadan dibolehkan oleh presiden republik Indonesia. Dengan itu kitab undang undang yang sudah di setujui itu hanya berlaku di Madura dan Jawa hanya terbatas itu saja. Dengan bolehnya kitab undang undang itu makan undang undang itu berlaku di seluruh Indonesia pada 20 sep 1958 dengan ditambahkan undang undang no 1 tahun 1946 yang dibuat oleh rakyat Indonesia itu sendiri yang mengatur tentang peraturan yang mengatur seluruh raka Indonesia yang menggantika undang undnagn sebelumnya yang belaku hanya di Jawa dan Madura yang dituangkan pada udang undang pasal 1 undnag undang no 7 dibuat pada tahun 1958 yang isinya adalah "undang-undnag no tahun 1946 negara Indonesia berlaku di seluruh negara ini",12) kemudian didalam KUHP, Pasal 340 soal pembunuhan berencana Pasal tersebut adalah Pasal pidana yang paling berat dan mematikan di dalam semua hukum pidana. ${ }^{13)}$ Pasal ini lah pasal yang dilayangkan kepada 3 orang dalam kasus pembunuhan di Pulomas yang menewaskan Dodi selaku tuan rumah di rumah tersebut beserta anak dan pegawai rumah tangga.

Menurut ahli hukum Titraamidjaja sebagai ahli, meluruskan direncanakan lebih dahulu antara lain sebagai bahwa ada suatu jangka waktu, bagaimanapun pendeknya untuk mempertimbangkan atau untuk berpikir tenang. ${ }^{14)}$ Menurut Agus

\footnotetext{
12) Anonim," sejarah KUHP dan KUHAP”, www.edukasippkn.com.

13) Tongat, Hukum Pidana Materiil, Tinjauan Atas Tindak Pidana Terhadap Subyek Hukum Dalam Kitab Undang-Undang Hukum Pidana. cetakan ke-1 (Jakarta: Djambatan, 2003). hal .20.

14) Tirtaamidjaja, pokok-pokok hukum pidana, (jakarta: fasco,1995), hal .12.
} 
Sulistyo dan Adi Mulyono selaku ahli hukum pidana, bahwa membunuh berasal dari kata bunuh itu sendiri yang berarti menghilangkan nyawa dan mematikan. ${ }^{15)}$ Ada perasaan yang mengganjal dimana sebagai penulis bahwa hakim memutus berdasarkan emosinya yang melihat tersangka ini adalah residivis. karena dalam pasal pembunuhan beencana KUHAP dinyatakan pembunuhan di ancam pidana 20 tahun. Namun putusan hakim memutus pidana mati dan pidana seumur hidup. yang menjadi mengenai kasus ini adalah karena 3 terdakwa yang masih hidup ini tidak berniat membunuh (satu dibunuh oleh polisi saat penangkapan). ${ }^{16)}$ Namun hanya menyekap sebelas orang yang ada dirumah Dodi, tetapi naas 6 dari 11 orang tersebut meninggal dunia dikarenakan kurang oksigen. menjadi banyak opini dikarenakan Dodi adalah seorang arsitek handal ditakutkan ini adalah pembunuhan karena bisnis. namun jika karena bisnis pasti Dodi di bunuh langsung. karena dimasukan di kamar mandi mungkin 3 orang ini hanya berniat meninggalkan rumah tanpa mendapat perlawanan dan hanya merampok. ${ }^{17)}$

\section{B. Perumusan Masalah}

Berdasarkan uraian latar belakang ini permasalahan yang ingin diteliti adalah bagaimanakah pembuktian unsur kesengajaan dalam tindak pidana pembunuhan dalam perkara no 328/PID/2017/PT.DKI?

\section{Metode Penelitian}

1. Tipe Penelitian

Metode penelitian yang penulis gunakan untuk membuat penelitian ini adalah metode penelitian normatif yang bersumber dari data sekunder . metode normatif adalah cara untuk mendapatkan data yang berasal dari bahasa pustaka itu sendiri atau dengan kata lainnya cara mendapatkan data sekunder. ${ }^{18)}$ Ruang Lingkup Penelitian Normatif adalah:

${ }^{15)}$ Agus Sulistyo dan Adi Mulyono, Kamus Lengkap Bahasa Indonesia, (Surakarta: Penerbit Ita, 2000), hlm 86.

16) Anonim,"Pembunuhan di Komplek Pulomas", www.detik.com, 22 maret 2017, hlm 3.

17) Anonim,"Arsitek Terkenal Meninggal", www.kompas.com, 28 februari 2017, hlm 1.

18) J.S.Badudu dan Sutan Moh Zain, Kamus Besar Bahasa Indonesia, (Jakarta: Pustaka Sinar Harapan, 1994), hlm 145. 
a. Penelitian terhadap asas-asas hukum Dalam hal ini dimaksudkan kepada asas-asas hukum yang berlaku. Contohnya, pada kajian hukum perdata indonesia, terdapat asas kebebasan berkontrak, yang mana bisa diteliti mengenai proses berjalannya asas ini yang merealitakan setiap individu bebas mengadakan perjanjian dengan mengisikan aturan-aturan yang hanya mengikat pihak-pihak yang berkontrak saja.

b. Penelitian terhadap sistematika hokum. Sistematika hukum itu sendiri berarti keteraturan sistem peraturan yang telah dirangkum sehingga bisa diterapkan secara seksama atau tepat. Dalam hal penelitian, bisa dikaji mengenai sistematika hukum yang berlaku di suatu negara.

c. Penelitian terhadap taraf sinkronisasi hukum dalam hal sinkronisasi hukum ini, yang berarti tidak bertentangannya suatu aturan dengan aturan lainnya, baik antara hukum yang bersifat lex spesialis dan lex superior maupun sebaliknya yang nantinya bisa dijadikan kajian penelitian jika ada pertauran yang demikian.

d. Penelitian sejarah hukum.

Dalam hal sejarah hokum ini, tentu saja ruang lingkup kajian penelitian bisa merangkup semua jenis dan aspek hukum dari teori-teori penemuan hukum sampai pada perkembangannya.

e. Penelitian terhadap perbandingan hukum.

Perbandingan hukum sebagai bahan penelitian bisa dilakukan dengan melakukan suatu perbandingan sistem hukum antara yang satu dengan sistem hukum lainnya.

Dari ruang lingkup penelitian normatif sendiri di atas yang penulis gunakan untuk membuat penelitian tentang pembunuhan ini adalah penelitian terhadap asas-asas hukum karena ingin meneliti tentang faktor kesalahan sebagai dolus dalam tindak pidana merampas nyawa milik orang lain.

\section{Sifat penelitian}

Spesifikasi penelitian yang akan dipakai di dalam penulisan Eti bersifat penelitian deskriptif dikarenakan memang membri data yang diteliti memungkinkan mengenai manusia, gejala gejala, keadaan dengan maksud 
utama mempertegas hipotesa, memperkuat teori yang sudah lama ataupun diperuntukkan membuay sistematis teori teori yang dianggap baru.

3. Alat Pengumpulan data.

Alat pengumpulan data yang dilakukan ini adalah mengumpulkan dan mempelajari berbagai jenis data sekunder ditinjau berdasarkan kekuatan mengikatnya dibedakan atas:

a. Bahan hukum primer, yaitu bahan hukum yang punya kekuatan mengikat berupa peraturan Undang-Undang, yurusprudensi, dan konvensi. Di dalam penelitian ini digunakan:

1). Undang-undang dasar negara republik indonesia tahun 1945.

2). Kitab undang-undang hukum pidana (KUHP)

b. Bahan hukum sekunder, ialah bahan hukum memang sangat kuat hubungannya dengan bahan hukum primer itu sendiri, kelebihannya dapat menganalisah, untuk paham, dan penjelasan bahan hukum primer itu, yang didalamnya adalah jurnal,makalah,laporan penelitian, dan buku. Pokok sekunder ialah berwujud buku buku yang berjudul penelitian hukum normatif, rencana tata ruang wilayah, serta jurnal-jurnal dan makalah yang berkaitan dengan penelitian ini saja.

c. Bahan hukum tersier, ialah pokok bahan yangmembri tunjukan ataupun jelasan atas bahan hukum primer dan sekunder, diliputi kamus, biografi, buku tahunan, buku petunjuk, indeks, dan lain-lain

\section{PEMBAHASAN}

\section{A. Tinjauan umum}

\section{Tinjauan Umum mengenai Delik Pembunuhan Berencana dalam KUHP}

Dalam KUHP diatur pada buku 2 pasal 338-350, menganai kejahatankejahatan yang merugikan nyawa orang. Pembunuhan adalah bagian tindak pidana material , artinya untuk kesempurnaannya tindakan ini tidak cukup dengan dilakukannya perbuatan itu sajamenjadi apa yang dibutuhkan di dalam perbuatan itu sendiri. Dasar dari perbuatan itu sendiri adalah dapat dibagi dalam dua bagian, yaitu dilihat dari kesalahan pelaku/subjective element dan sasaran /objective element. Jika didasarkan pada kesalahan pelakunya, maka diperinci atau dikerucutkan atas dua golongan, yakni: 
a. Kejahatan yang ditujukan atau dikhususkan terhadap nyawa manusia yang dilakukan secara sengaja/dolense misdrijven. Terdapat pada pasal 338 sampai 350 KUHP Indonesia.

b. Kejahatan yang diperuntukan untuk nyawa manusia yang terjadi karena kealpaan/culpose misdrijven. Terdapat pada Pasal 359 KUHP. Sedangkan jika didasarkan kepada sasaranya, dibedakan kepada tiga macam:

1). kriminal yang ditujukan kepada jiwa manusia pada umumya.

2). Kriminal yang ditujukan kepada jiwa seseorang anak yang sedang atau belum lama dilahirkan.

3). Kriminal yang ditujukan terhadap nyawa seseorang anak yang masih dalam kandungan ibunya.

\section{Tinjauan Umum mengenai Pengaturan Pembuktian Pembunuhan}

\section{Berencana di Indonesia.}

Pembuktian kepada satu perbuatan pidana yang permasuk ketentuan yang ada sisinya pengarissan dan cara dari cara yang tepatkan oleh undang undang yang dapat memberi bukti salah yang ditujukan kepada yang dituju, membuktikan ini juga adalah ketentuan yang juga menyuruh alat bukti yang membenarkan undang undang yang Diana hakim mempergunakannya untuk memberi bukti salah kepada yang ditujukan tadi. Membuktikan adalah titik tengah di Salamah acara sidang di pengadilan, dikarenakan di dalam perlakuan ini, bisa menentukan hasil akhir dari yang ditujukan. Jika hasilnya dari pembuktian ini dengan alat bukti yang ada di bolehkan oleh undang undang tidak mencukupi untuk menghukum yang dituju maka yang dituju itu dapat dilepaskan dari jerat hukum yang menuimpanya. Maka anonimnya jika kesalahannya itu nampak maka yang ditujukan itu dinyatakan salah dan oleh karena itu sendiri dia diberi hukuman yang setimpal.. 
Menurut Pitlo filsuf hukum, pembuktian sendiri adalah satu cara yang diperbuat oleh orang. Pembuktian tentang apa benar atau tidaknya terdakwa melakukan perbuatan yang didakwakan adalah merupakan bagian yang sangat penting dalam hukum acara pidana di indonesia. Membuktikan itu sendiri diartikan memberi kepastian kepada majelis hakim mengenai adanya peristiwa tertentu yang terjadi.

\section{B. Teori-teori}

\section{Teori Pembuktian}

Teori pembuktian ini adalah pengaturan tentang macamdari sanyak alat bukti yang yang dibolehkan dalam persidangan, penjabaran alat bukti, dan dengan cara agar majelis dapat membuat yakin dalam dirinya di depan persidangan yang dijalani ${ }^{19}$ ) Sistem pembuktiannya, ialah suatu cara yang isinya pertama tentang semua alat alat bukti yang didapat atau bolehkan pakai untuk membuktikan, jalan agar alat tersebut dapat digunakan dan kasta dari alat tersebut juga dijadikan tolak ukur dalam ambil putusan kesimpulan dari semuanya tentang membuktikan sesuatu. Pembuktian adalah kesempurnaan dari semuanya perihal membuktikan yang saling berhubungan satu dan lainnya dan tidak terpisahkan. ${ }^{20)}$

Maksud yang dilaksanakannya kegiatan ini yang diatur dalam Pasal 183 KUHAP adalah untuk mengambil satu putusan menarik dari amar putusan oleh majelis hakim. Pembuktian dilakukan pertama dalam usaha mencapai keadilan tertinggi dan kepastian hukum yang setinggi-tingginya dalam putusan yang terakhir dari hakim. Agar pembuktian tidak hanya ditujukan untuk menjatuhkan

19) Alfitra, Hukum Pembuktian dalam beracara Pidana, Perdata dan Korupsi di Indonesia, (Jakarta: Raih Asa Sukses, 2011), hlm 28.

${ }^{20)}$ Adhami Chazawi, Hukum Pembuktian Tindak Pidana Korupsi, (Bandung: Alumni, 2008), hlm 24. 
pidana saja berdasarkan syarat minimal dua alat bukti yang harus dipenuhi dalam hal pembuktian untuk menjatuhkan pidanakepada seseorang. ${ }^{21)}$

\section{Teori Kesengajaan (dolus)}

Kesengajaan adalah merupakan satu dari banyak bagian dari kesalahan. kesengajaan pelaku memiliki hubungan kejiwaan yang sangat erat terhadap suatu pweilaku yang terlarang dibanding dengan kealpaan/culpa.

a. Teori kehendak/wilstheorie adalah inti kesengajaan ini adalah keinginan untuk mewujudkan unsur delik dalam rumusan perundangan pidana.

b. Teori pengetahuan/membayangkan/voorstellingtheorie adalah Sengaja yang berarti memikirkan akan akibat timbulnya akibat perbuatannya orang tak bisa menghendaki akibat, melainkan hanya dapat memikirkannya saja. Teori ini berpusat pada apa dipikirkan oleh pelaku ialah apa yang akan terjadi pada saat ia akan berbuat nantinya.

Jenis kesengajaan Dalam ilmu hukum pidana, kesenggajaan /dolus mengenal adanya berbagai macam kesenggajaan, antara lain:

(1). Aberratio ictus yaitu kesengajaan yang dimana satu subyek yang sengaja melakukan kejahatan untuk tujuan terhadap objek tertentu, tapi ternyata mengenai objek yang lain.

(2). Dolus premeditates, yaitu kesengajaan dengan direncanakan terlebih dahulu.

(3). Dolus determinatus, yaitu kesengajaan dengan tingkat kepastian objek, misalnya mengingini matinya seseorang.

(4). Dolus indeterminatus, yaitu kesengajaan atau dolus dengan tingkat ketidakpastian objek, misalnya menembaki segerombolan orang dalam kerumunan.

\footnotetext{
${ }^{21)}$ Adhami Chazawi, Op cit, Hlm 31.
} 
(5). Dolus alternatives, yaitu kesengajaan dimana pelaku dapat memperkirakan satu dan lain akibat. Misalnya meracuni sumur milik orang lain.

(6). Dolus directus, yaitu kesengajaan yang tidak hanya ditujukan kepada perbuatannya, tetapi juga kepada akibat perbuatannya itu sendiri.

(7). Dolus indirectus yaitu bentuk kesengajaaan yang menyakini bahwa semua akibat dari perbuatan yang sengaja dilakukan, ditargetkan atau tidak ditargetkan, diduga atau tidak menduga, itu anggapannya sebagai hal yang ditimbulkan dengan sengajaan. Misalkan didalam pertengkaran seseorang mendorong temannya, kemudian terjatuh dan tergilas mobil di tengah jalan.

\section{Kealpaan (culpa)}

Kealpaan adalah salah satu wujud dari kesalahan. Kealpaan adalah bentuk yang paling rendah kastaanya dibandingkan kesengajaan. Tetapi dapat juga dibilang bahwa kealpaan itu sendiri adalah anonim dari kesengajaan, karena jika mana dalam kesengajaan, sesuatu akibat yang terjadi itu dikehendaki, walaupun terdakwa dapat memperaktikkan sebelumnya. Nanti di sinilah juga letak salah satu kesusahan untuk memgkontraskan antara kesengajaan bersyarat/dolus eventualis dengan kealpaan berat/culpa lata.

Kata culpa atau sengaja ini dalam arti besar berarti kesalahan yang umum, sedang dalam arti sempitnya adalah wujud salah yang berupa kealpaan. Alasan mengapa culpa menjadi salah satu unsur kesalahan adalah jikamana suatu keadaan, yang segitu membahayakan keamanan manusia atau barang, atau memberikan kerugian terhadap ssatu orang yang segitu besarnya dan tidak dapat diperbaiki lagi. jadi, jika undang-undang juga bertindak terhadap larangan penghati-hati, sikap senaknya endiri dan pendek kata schuld atau diartikan kealpaan yang menyebabkan keadaan seperti yang diterangkan tadi. intinya, suatu tindak pidana diikuti kealpaan, dimana adanya perbuatan pidana yang 
dilakukan karena kurang dugaan atau kurang berhati-hati.contohnya, mengendarai kendaraan beroda empat dengan kecepatan tinggi menjadi hilang kendali sehingga menabrak orang dan menyebakan orang yang ditabrak tersebut meninggal dunia.

Pemahaman dari kealpaan secara letterlijk tidak ada dalam KUHP, dan berbagai literatur yang kami kumpulan dalam pembahasan ini.kemudian untuk gampangnya di dalam pemahama mengenai kealpaan lebih baiknya dipaparkan di dalam contoh yang mudah contohnya seperti tidak meroko kemudian di buang di tumpukan jerami yang berbentuk rumah ataupun ke barang yang mudah terbakar yang nantinya malah membuat kebakaran.tidak buat sesuatu untuk memberitahu bahwa ada pekerjaan galian sehingga seseornag tersungkur masuk ke dalamnya. Pada umumnya kealpaan dapat dibedakan dalam bentuk, antara lain:

1). Kealpaan yang disadari/bewuste schuld.

Pengertiannya ini si pelaku dapat teringat tentang apa yang dilakukan juga akibatnya, akan tetapi ia percaya dan mengharapkan bahwa akibatnya tidak akan terjadi lagi.

2). Kealpaan yang tidak disadari/onbewuste schuld

Di sini seseorang dapat melakukan sesuatu yang tidak didasari kemungkinan akan terjadi sesuatu hal, padahal dapat didugakan sebelumnya.

Bedanya itu bukan artinya kealpaan yang sadar itu sendiri sifatnya lebih parah dibandingkan kealpaan yang tak disadari. Kerap kali oleh itu malah tanpa dipikirkan muncul kemungkinan-kemungkinan muncul sesuatu yang berat. Ban hattum berpesan, jika kealpaan yang sadar itu ialah nama yang ringan untuk terjadi kemungkinan thdp pelaku yang tidak lain adalah dlous eventualis . kemudian bedanya ini sedikit arti. Kealpaan itu juga adalah pengertian yang disebut normatif salah dari salah suatu pengertian yang dinyatakan keadaan. Ketentuan alpa seseorang keharusan lakukan dari luar, jikalau harus di 
simpulkan dilihat dari sisi tertentu, bagaimanakah seseorang atau pelaku itu bertindak.

Berdasarkan analisis penelitian penulis pembuktian unsur kesengajaan dalam tindak pidana pembunuhan putusan No328/PID/2017/PT.DKI kurang tepat karena lebih masuk ke dalam kategori pencurian yang disertai kekerasan di pasal pencurian dengan kekerasan karena niat awalnya bukan untuk membunuh namun mencuri dan kesengajaannya juga untuk mencuri. maka penulis berpendapat bahwa Pertimbangan hukum yang dijatuhkan oleh hakim terhadap terdakwa dalam kasus tersebut dinilai kurang tepat karena hanya berniat untuk mencuri bukan untuk membunuh. Dari awal merencanakan niat jahat ini dari mulai menyiapkan strategi pencurian sampai melaksanakannya diniatkan untuk merampas harta yang ada di dalam rumah dibilangan pulomas tersebut, namun aksinya dilanjutkan mengurung semua orang seisi rumah di dalam kamar mandi kecil lalu meninggalkannya. Aksi mengurung semua orang seisi rumah tersebut guna untuk memperlambat pengejaran terhadap pelaku kejahatan namun naas orang yang dimasukan ke dalam kamar mandi tersebut kekurangan oksigen lalu menginggal dunia oleh karena itu pengadilan mentuntut pertanggung jawaban terdakwa dengan pasal 340 KUHP karena telah menghilangkan nyawa milik orang lain.

Proses peradilan di indonesia berujung putusan dan pembuktian terakhir yang didalamnya terdapat putusan sanksi-sanksi pidana, di dalam putusan itu majelis memberikan pendapat oleh yang telah dipikirkannya dan menjadi dasar dari putusannya. Di dalam upaya merangkai keputusan juga memberikan hukuman terhadap seseorang, hakimlah orang yang tepat yang seharusnya punya pertimbangan pertimbangan yuridis berisikan dari dakwaan jaksa penuntut umum,ket terdakwa, ket saksi, barang bukti, dan pasal perbuatan hukum pidana itu sendiri dan pertimbangan on yurudis dan fakta yuridis yang 
berisikan daripada latar blkng yang dilakukan seseornag, yang menambah hakim untuk meyakinii seseorang itu melakukan perbuatan melawan hukum atau tidak yang ditujukan atau tidak sebagaimana yang ditentukan oleh hukum di bangsa ini. Pengambilan keputusan perlu sekali oleh seorang majelis hakim untuk mengelola dan melaksanakan semua data yang didapat saat sidang berjalan yang sudah berlaku yang di dalamnya adalah bukti,ket saksi, pembelaann, disertai penuntutan dari jaksa penuntut umumnya ataupun muatan psikologis. Sehingga putusan yang dilayangkan kepada kepada terdakwa dapat didasari oleh rasa tanggungjawab, rasakeadilan, rasakebijaksanaan, dan kesahajaan yang tinggi berhubungan dan kasus yang saya tulis.

\section{Analisis pembuktian perkara pembunuhan No328/PID/2017/PT.DKI}

Berdasarkan analisis penelitian penulis pembuktian unsur kesengajaan dalam tindak pidana pembunuhan putusan No328/PID/2017/PT.DKI dinilai kurang tepat karena lebih masuk ke dalam kategori pembunuhan biasa pada pasal 338 KUHP karena pada Pasal 340 KUHP dimuat unsurnya adalah kesengajaan dan kesengajaannya juga harus sengaja untuk membunuh bukan yang lain. Maka pertimbangan hakim itu dinilai kurang tepat karena unsur kesengajaannya masih harus didalami lagi.

Apabila kita bertolak ukur ke dalam KUHP, segera dapat diketahui bahwa pembuat undang-undang yang ditujukan terhadap nyawa orang lain dalam Buku ke 2 KUHP yang terdiri dari tiga belas pasal, yaitu dari Pasal 338 sampai dengan Pasal 350.

Kriminalitas kepada nyawa seseorang yang dijalani pelaku dengan kesengajaan dapat dikatakan ataupun beri kualifikasi sebagai pembunuhan biasa di dalam bntk pokok. Kriminal ini menuju terhadap nyawa seseorang yang dilakukannya dan sengaja di dalam hal ini pembunuhan di dalam bentuk pokok, yg dimuat dalam pasal 338 kitab undang undang hukum pidana.

Adapun unsur tindak pidana dalam Pasal 338 KUHP adalah sebagai berikut: 
a. Unsur sengaja mmeliputi tindakan dan berarti orang tersebut mengingini orang meninggal dari perbuatannya tersebut. Ilangnya nyawa harus diingini, agar perbuatan dilakukan dengan tujuan menghilangkan nyawa milik orang lain.

b. Terjadi akibat itu sengaja atau tidak bukan ingin diniatkan maka tidak dapat dikenakan ketentuannya mungkin tapi dikenakan pasal lain yang sama dengan itu.

c. Akibatnya harus menimbulkan kesengajaan dilakukannya, harus dilakukan dengan penuh kesengajaan, jadi pelaku harus menghendaki perbuatannya itu dapat bahkan pasti mengakibatkan adanya orang mati.

d. Untuk memenuhi unsur yang terdapat pada Pasal 338 KUHP ini disyaratkan bahwa perbuatan pembunuhan tersebut harus dilakukan secepat mungkin setelah di ingini dalam hatinya tanpa berfikir dahulu atau tidak dengan suatu perencanaan.

e. Sulit utntuk mempraktekan unsur sengaja itu,apalagi jika pelaku ingin menutupinya. Karena sengaja adalah unsur subyektid dari si pelaku pidana dilihat dari perkataannya di polisi maupun di pengadilan,terkecuali pelaku mengatakannya dengan jujur atau di dalam hatinya ingin mengatakan yang sebenarnya terjadi pda dirinya pada saat melakukan itu.

f. Biasanya di masyarakat setempat kasus pidana pembunuhan pelakunya dapat menghindar atau berusaha menghindar untuk mengaku dari kesengajaannya tetapi bersembunyi di balik unsur ketidak sengajaanya wahwa pelaku tidak sengaja melakukan itu atau menjadi pengakuannya hanya ingin melukai korban saja.

g. Buat membuktikannya sengaja ini menurut ketentuan harus dilihat perlakuannya disalam merealisasikan perbuatan jahat pelaku tersebut. Sampai dikehendaki atau diharapkan agar korban tersebut meninggal.

h. Menghilangkan jiwa orang lain; 
- harus adanya orang mati. Dan yang mati adalah bukan pelakunya namun orang lain.

- yang disebut orang lain adalah seseorang diluar pelaku tersebut.

- dalam pasal 338 tersebut tidak ada penjelasannya bagaimana hal itu dilakukan perbuatan itu dijalani, tidak ditentukan juga cara membunuhnya dengan alat apa, tetapi peraturannya yang menegaskannya yaitu menghilangkan nyawa orang lain selain diri pelaku.

- hasil dari pembunuhan itu tidak terjadi cepat dan sangat cepat. Tapi bisa jadi terjadi dikemudian hari.

-untuk melengkapi unsur dari pasal tersebut matinya orang lain itu harus ada suatu perlakuan, jikapun perbuatan itu kecil yang berakibat menginggalnya orang lain.

Unsur perbedaan subjektif kesengajaan dengan bentuk perbuatan yang menghilangkan nyawa milik orang lain harus cepat dari terjadinya keinginan untuk membunuh tersebut bahasa lainya keinginan pelaku melakukan perbuatannya untuk merampas nyawa orang lain . jadi apabila ada waktu tenggang di dalamnya maka akan terdapat pemikiran berbagai hal jika dipikirakan dulu itu masuknya ke pembunuhan berenccana di pasal 340 KUHP bukan lagi pembunuham biasa.

Jika dilihat dari pasal 338 KUHP yang ada di Indonesia dan berlaku sekarang. cepat dapat dilihat kesengajaan itu ada di depan unsur mengilangkan nyawa atau merampas nyawa orang lain tersebut, ini berarti jika dibelakangnya letaknya maka tidak di belakang maka tidak termasuk. Maka di pengadilan harus ditunjukan semuanya yang telah terjadi yang di depan taua di balakang itu tadi.

Menurut pengelihatan pengamat sendiri bahwa unsur itu dapat dimasukan ke dalam rumusakn hukum pidana, jadi pengertiannya itu dapat diartikan masuk ke dalam 3 jenis kesengajaan itu tadi, pengelihatan ini sesuai dengan praktik hukum yang ada di Negara ini. 
Teori yang tepat pada kasus ini adalah Teori kesengajaan karena kesengajaan pelaku hanya untuk mengambil barang di rumah tersebut bukan untuk membunuh dalam teori kesengajaan ada teori kehendak dimana kehendak pelaku membayangkan jika dikurung di kamar mandi maka seisi rumah akan lambat mengejar pelaku namun yang terjadi adalah yang tidak dibayangkan pelaku jika yang ia lakukan menghilangkan nyawa milik orang lain. maka pengertian hukum dari kesengajaan dapat diartikan menghendaki dan tahu apa uyang ingin ia perbuat atau yang ingin dilakukannya atau yang dikenal dengan memori penjelasan yang mengartikan kesengajaan sebagai mengingini dan menghendaki dan mengetahui. Kesengajaan bagusnya memiliki 3 unsur tindak pidana, adalah yang dilarang, akibat yang jadi pokok asalan alasan adanya peraturan itu, dan perbuatannya harus delik. dalam pemikiran ini kesengajaannya berarti mengingini atau menghendaki.

Analisa kesengajaan pada kasus pembunuhan 328/PID/2017/PT.DKI adalah benar adanya si pelaku sengaja membuat strategi untuk mencuri barang yang ada di dalam rumah di pulomas tersebut. Kesengajaan yang dilakukan pelaku masuk ke dalam kategori teori kesengajaan yang sudah di paparkan kesengajaan sebagai menghendaki dan mengetahui apa yang akan mereka lakukan.

Mirip dengan yang telah dipaparkan sebelumnya bahwa kesengajaan yang ada dalam ranah hukum pidana artinya adalah bagian dari kesalahan. Kesengajaan dari pelaku yang ada hubungan kejiawaan yang erat dari tindakan yang dilarang oleh hukum dibandingkan dengan kealpaan atau culpa. Hukum pidana pada satu perbuatan melanggar hukum yang lampau lebih susah, jika adanya kesengajaan dibanding kealpaan di pasal 338 KUHP caranya memberi tahu unsur tingkah laku yang harus dilakukan sebagai yang merampas nyawa orang lain, memberti tahu jika kejahatan pembunuhan adalah perbuatan materil. Materil adalah perilaku yang menjadikan suatu akibat (tidak diperbolehkan).

Perilaku menghilangkan nyawa kemilikan orang lain di rumuskan didalam wujud aktif dan susah di jelaskan. Wujud aktif dari menghilangkan nyawa 
kemilikan orang lain tersebut artinya mengadakan perilaku itu harus dengan gerakan manusia yang ada pada tubuhnya, tidak dibolehkan diam atau pasif, disebut susah dijelaskan karena perilakunya tidak memberikan sesuatu yang konkrit. Jadi karena itu dengan kenyataan yang konkkrit tadi perilaku itu sendiri disa dikategorikan bermacam-macam bentuknya contohnya membacok, mengiris, menembak. Dan banyak sekali bentuk bedanya.

Awal merencanakan niat jahat ini dari mulai menyiapkan strategi pencurian sampai melaksanakannya diniatkan untuk merampas harta yang ada di dalam rumah dibilangan pulomas tersebut, namun aksinya dilanjutkan mengurung semua orang seisi rumah di dalam kamar mandi kecil lalu meninggalkannya. Aksi mengurung semua orang seisi rumah tersebut guna untuk memperlambat pengejaran terhadap pelaku kejahatan namun naas orang yang dimasukan ke dalam kamar mandi tersebut kekurangan oksigen lalu menginggal dunia oleh karena itu pengadilan mentuntut pertanggung jawaban terdakwa dengan pasal 340 KUHP karena telah menghilangkan nyawa milik orang lain. Apabila dikaitkan dengan posisi kasus yang telah dibahas sebelumnya maka inti delik yang dipenuhi dari perbuatan itu dapat di hukum adalah Unsur menghilangkan nyawa orang lain.

Dilihat menurut tanggung jawab pidananya itu sendiri, jadi tanggung jawabnya menurut hukum pidana, ada 3 syarat antara lain:

Kehebatan mempertanggung jawabkan /bisa dipertanggung jawabken dari sipelaku

Ada perilaku yang melenceng dr hukum adalah salah satu sikap psikis dari pelawan hukum yang berkaitan dengan perilakunya adalah sengaja, kurang hati hatiatau culpa dengan tidak adanya pembenaran atau sesuatu yang menghapus pertanggung jawaban pembuat onarnya

Jika di atas sulit untuk dilakukan dengan waktu yang lama, jadi unsur kemampuan bertanggung jawabnya Cuma dikecualikan jika dia gila. Jadi di dalam hal ini majelis menyuruh untuk jangan diminta dengan terdakwa. 
Sedangkan pelaku dalam ini sejauh ini terlihat ok, tidak ada tanda sesuatu yg bilang bahwa dia gila.

Kesimpulan berdasarkan hasil analisis penulis, maka penulis berpendapat bahwa penerapan hukum pidana materil pada perkara ini yakni Pasal 340 KUHP kurang tepat dengan peraturan perundang-undangan yang berlaku karena lebih tepat diterapkan di pasal 338 KUHP oleh karena penjabaran di atas.

\section{PENUTUP}

\section{A. Kesimpulan}

Berdasarkan uraian penulis, maka penulis dapat berkesimpulan pembuktian unsur kesengajaan dalam tindak pidana pembunuhan dalam perkara no328/PID/2017/PT.DKI yang menurut hakim adalah 340 kurang tepat karena menurut penulis lebih tepat di pasal 338 KUHP karena perbedaan tara 340KUHP adalah pembunuhan berencana kemudian 338 KUHP adalah pembunuhan biasa jadi di dalam niat pelaku harus di dalami lebih lanjut sesuai undang-undang yang berlaku. Hakim harus mempertimbangkan sesuai inti delik bukan hanya karena tekanan dari masyarakat.

Analisis ini deiterapkan di kasus pembunuhan berencana, penerapannya ini yakni pasal 340 KUHP dengan semua yang telah terjadi bahwa pelau yang melakukannya itu tidk gila dan bisa beracara di pengadilan. sehingga dianggap mampu mempertaanggung jawabkan perbuatannya. Pemikiran hakim dalam memutus perkara 328/PID/2017/PT.DKI dengan masuknya unsur pada Pasal 340 KUHP, juga semua keterangan-keterangan yang hakim dapat di dalam persidangan menambah yakin hakim untuk memutus tanpa mengingat bahwa hakim harus memikirkan hal yang meringankan dan memberatkan kepada si pelaku.

Pemikiran majelis yang ditujukan dari majelis kepada terdakwa di perkara ini tidak sesuai dengan teori hukum yang ada khususnya pemidanaan. Karena untuk itu banyak sekali kelemahan didalam memberikan sanksi kepada pelaku pidana maka majelis harus memikirkan kembali hal yang meringankan dan meyulitkan 
agar ada kesempatan bagi pelaku untuk bertaubat dan berksempatan untuk hidup makan buruk dalam putusan tidak mencantukan yang meringankan dan menyulitkan.

\section{B. Saran}

Saran yang diberikan oleh penulis dalam penulisan ini adalah penulis berharap dengan jangka waktu pemeriksaan yang tepat, majelis hakim sepatutnya betulbetul mempertimbangan fakta-fakta yang terungkap di Pengadilan dan juga hati nuraninya. Hakim harus mempertimbangkan sesuai inti delik bukan karena ada tekanan dari masyarakat. walaupun banyak tekanan maka undang-undanglah yang menjadi dasar putusan. 


\section{DAFTAR PUSTAKA}

\section{A. Buku}

Ali,achmad. Menguak Tabir Hukum. Bogor: Ghalia Indonesia, 2008.

Alfitra. Hukum Pembuktian Dalam Beracara Pidana, Perdata dan Korupsi di Indonesia. Jakarta: Raih Asa Sukses, 2011.

Apeldoorn, L.J.Van. "Pengantar Ilmu Hukum". Jakarta: pradnya paramita, 1933.

Badudu, J.S. dan Sutan Mohammad Zain. Kamus Besar Bahasa Indonesia.

jakarta: Pustaka Sinar Harapan, 1994.

Chazawi, Adami. Pelajaran Hukum Pidana 1. Jakarta: PT.raja Grafindo Persada 2001. . Hukum Pembuktian Tindak Pidana Korupsi. Bandung: Alumni, 2008.

Hamzah, Andi. stelsel pidana \& pemidanaan di Indonesia, Jakarta: Pradja Paramita, 1993.

Muhammad Rusli. Hukum Acara Pidana Kontemporer. Bandung: Citra Aditya Bakti, 2007.

Sulistyo, Agus dan Adi Mulyono. Kamus Lengkap Bahasa Indonesia. Surakarta: Penerbit Ita, 2000.

Prakoso, djoko. Masalah Pemberian Pidana Dalam Teori dan Praktek Peradilan. cetakan ke-1. jakarta: Ghalia indonesia, 1984.

Priatno, Widya. sistem pelaksanaan penjara di Indonesia, Jakarta: PT:refika aditama,2005.

Puspa, Yan Pramadya. Kamus Hukum Edisi Lengkap Bahasa Belanda, Indonesia, Inggris. Semarang: Aneka Ilmu, 1977.

Tirtaamidjaja. Pokok-Pokok Hukum Pidana. jakarta: fasco, 1995.

Tongat. Hukum Pidana Materiil, Tinjauan Atas Tindak Pidana TerhadapSubyek Hukum dalam Kitab Undang-Undang Hukum Pidana. cetakan ke-1. Jakarta: Djambatan, 2003.

Press, 2005

. pidana seumur hidup dalam sistem hukum pidana di Indonesia, malang: UMM

\section{B. Undang-undang}

Indonesia. Undang- undang Dasar Negara Republik Indonesia tahun 1945.

Indonesia. Kitab undang-undang hukum pidana.

\section{Putusan}

Putusan pengadilan tinggi nomor: 328/PID/2017/PT.DKI

\section{Website}

Pratama, Akhdi Martin."Arsitek terkenal meninggal”. www.kompas.com, 28 Februari 2017.

Shenny Fierdha. "polisi catat jumlah kriminal". www.anadoluagency.com, 29 Desember 2017.

Sirait, anton. "sejarah KUHP dan KUHAP”.www.edukasippkn.com. 
Taufiqqurahman, Muhammad."pembunuhan di komplek pulomas". www.detik.com, 22 Maret 2017. 